\title{
Quality standardization - a factor of sustainable competitiveness of companies in Serbia
}

\author{
Стандардизација квалитета - фактор одрживе \\ конкурентности предузећа у Србији
}

\author{
Vuk Miletić * \\ The College of Academic Studies “Dositej”, Belgrade, Republic of Serbia, vukmiletic88@gmail.com \\ Nikola Ćurčić \\ The Institute of Agricultural Economics, Belgrade, Republic of Serbia, nikolavcurcic@yahoo.com \\ Zoran Simonović \\ The Institute of Agricultural Economics, Belgrade, Republic of Serbia, zoki@medianis.net
}

\begin{abstract}
The analysis of the possibilities of creating the sustainable competitiveness of an enterprise from the point of view of the functional uniformity of economic and ecological sustainability, as well as the production of products in compliance with the international standards for business operations, is the subject matter of the research conducted in this paper. The achievement of a higher level of competitiveness is a strategic goal of every enterprise, while the competitiveness of a product implies an appropriate standardization of quality. The starting assumption is that in order for enterprises to become competitive not only on the domestic market, but on the international market as well, it is necessary that they should standardize their business operations by improving the quality system. The goal is to gain an insight into how much significance domestic enterprises give to the standardization of quality, apart from the other needed factors, how interested they are in investing in the implementation of the ISO 9000:2000 standards, which are primarily oriented towards the satisfaction of client requirements, thus improving their own business operations. In this research study, the hypothetical-deductive methods, analytical-deductive and comparative methods, historical and statistical-descriptive methods, as well as the comparative statistical methods (ch2 Test, ANOVA), are used.
\end{abstract}

Keywords: standardization, quality of business operations, competitiveness, enterprise JEL classification: L15, M21

Сажетак: Предмет истраживања у овом раду је анализа могућности креирања одрживе конкурентности предузећа са аспекта функционалног јединства економске и еколошке одрживости, те продукције производа сагласно међународним станадардима пословања. Постизање вишег нивоа конкурентности стратешки је циљ сваког предузећа, док конкурентност производа подразумева одговарајућу стандардизацију квалитета. Полазна претпоставка је да би предузећа постала конкурентна како на домаћем, тако и на међународном тржишту неопходно је да стандардизују своје пословање, унапређењем система квалитета. Циљ је да се сагледа колико домаћа предузећа поред осталих потребних фактора придају значај стандардизацији квалитета, колико су заинтересовани за инвестирање у имплементацију стандарда ИСО 9000:2000 који су превасходно оријентисани на задовољење захтева клијената и тиме унапредила своје пословање. У овом истраживању коришћене су хипотетско дедуктивне методе, аналитичко - дедуктивне и компаративне методе, историјске и статистичко дескриптивне методе и методе компаративне статистике (ch2 Test, ANOVA).

* Corresponding author 
Кључне речи: стандардизација, квалитет пословања, конкурентност, предузеће. JEЛ класификација: L15, M21

\section{Introduction}

More than ever before, enterprises are faced with foundational changes in the manner they operate in today. The digital economy is a reality (Domazet et al., 2018), and the challenges of standardization are ever more complex. For that reason, business practice and theory are repeatedly and anew estimated so that organizations can survive in the market, increase their market shares, reduce their costs, raise the quality of their products, or achieve and keep their competitive advantage (Ćurčić \& Miletić, 2020). The achievement of a higher level of competitiveness is a strategic goal pursued by every enterprise, while the competitiveness of products implies an appropriate standardization of quality.

The problem of the sustainable competitiveness of an enterprise should be considered from an integral standpoint - the functional uniformity of economic and ecological sustainability (Krstić et al., 2018), as well as the production of products in compliance with the international standards for business operations. The organization of business operations in compliance with the said criteria enables an enterprise to acquire and keep an advantage in relation to its rivals, first of all through the creation of a larger space in the market (Olavarrieta \& Friedmann, 2008, p. 623-630).

Irrespective of the trend of growth of the number of the organizations that have introduced a quality management system, as well as the development of the movement for quality in the domestic economy, generally viewed, the results have not been satisfactory yet. The standardization process has been conducted slowly, both due to the insufficient knowledge of the information about the importance of the standards for the business operations of national enterprises and the impossibility of effectively fulfilling the requirements imposed by the standards, and so forth. The reality of the international market and the business environment (Miletić et al., 2020) exerts an influence on Serbian organizations' managers' understanding of the need and their becoming more interested in investing in the implementation of the ISO 9000:2000 standards, which are primarily oriented towards the satisfaction of client requirements as one of the elementary preconditions for the permanent improvement of the quality of business operations (Cvjetković \& Ilić, 2015). However, there is a pronounced delay, given the fact that the competition is strong and that it has established in the market, so it is difficult to find one's own "niche".

In longstanding practice (Arsovski, 2013, A-2.), since the very first major revision of the standards, numerous problems related to its role have been noticed. One part of the problem is connected with the inadequately applied process approach, and the fact that the role of a manager/leader in it has not been determined in a clear manner, either. Apart from the low level of labor productivity and the inadequate price-product quality ratio, the insufficient application of the quality management system is still singled out as the key problem of the insufficient market successfulness of the business operations carried out by 
Serbian enterprises, especially by small and medium-sized enterprises, which significantly influences their competitiveness both in the domestic market and in the international market. "Quality", as the satisfaction of the need and desire for living in a quality manner, is exactly the backbone in the quality management concept. Management has been recognized as one of the key success factors in the establishment of the quality management system, too, (QMS - Quality Management System), which is presented in a precise manner in the mentioned (ISO 9000:2000) standard series.

The need of the Serbian organization (Miletić et al., 2017, p. 75) to meet the expectations of different buyers/consumers for goods requires the application of the international standards for business operations that are related to the quality concept, without which there is no success in business. Apart from the state and its institutions, organizational managers/leaders with their initiatives also have an important role in the promotion of the international standards for business operations in the function of raising the competitiveness level.

\section{The standardization of business operations and its benefits in an organization}

As the process of the application of appropriate standards in order to make or improve a product or labor process (Milovanov, 2016), standardization is ultimately aimed at eliminating problems and maximizing performances in the work of an enterprise. Business operations quality standardization is a factor critical for the survival of the organization in the global economy (Šarović, 2014), and simultaneously both the path and the way to lower trade barriers and successfully compete with global actors. If a concrete organization cannot work without everyday operational engagement, it is time for standardization.

A standard is a document which defines the process and manner of performing a certain business activity, the basic characteristics of the process and the expected results of the process. Standards serve to set certain successfulness parameters (KPI - Key Performance Indicators) so as to be able to monitor effects (www.datalab.rs/znacajstandarda-u-poslovanju/). They are necessary for every kind of business operations, even for micro-enterprises, given the fact that they give a form to and establish a market. A predefined, documented manner of working saves time and money, even when that is not so much obvious. Standards help bring into compliance the technical characteristics of products and services, by means of which they make industry more efficient and help eliminate obstacles in international trade. They contribute to an increase in buyer satisfaction, and ultimately help their more efficient management.

As the internationally recognized norms that define the rules and guidelines for the quality of production (Soković et al., 2009), the end product, the ISO standards can be applied to any organization independently of its size, type, production and service. They are a proof that the organization is capable of producing quality products (Popović, 2013) or offering a quality service. Compliance with the international standards helps consumers to be aware of the fact that the products they buy are safe, characterized by appropriate 
performances, and that they are not a threat to their health and the environment. They simultaneously enable a reduction in the risks buyers are exposed to, such as omissions in the data safety system.

The quality of products plays the key role in the market. Producers of goods and service providers are basically interested in a more specific assessment of the quality of a product or service (Milunović-Koprivica et. al., 2019) in order to make a certain improvement based on it. By ensuring consistent quality (Oakland, 2005), organizations conquer new markets, and also retain the existing ones. End-user and client expectations imply that the product they buy will, with respect to the quality of the product, meet their requirements and needs (Bobera et al., 2017, p. 117-127). For that reason, only those organizations that hold on to quality, and simultaneously to their own buyers, can be considered as competitive and successful.

When products and services are brought into compliance with applicable standards, both consumers and business partners as well can trust in their safety, reliability and quality (Božilović \& Miletić, 2014). The experiences in the application of standards and in the participation in the standardization process that Serbian enterprises have gained so far are indicative of the fact that no high level of understanding that it is one of the decisive factors for raising competitiveness, the quality of business operations and export has been reached yet (Aničić et al., 2019). Standardization will enable Serbian enterprises to achieve a more favorable position in contacts with government institutions, at tenders, and so on. Standardization enables them to meet the contemporary requirements made by the market and eliminate barriers to efficient business operations not only in the domestic market, but in the international market as well.

Today, organizations throughout the world apply, either individually and/or jointly, a larger number of standards for different management systems in the enterprise. The largest number of them have been developed and applied in the field of the QMS, business continuity management, and so on. The research studies carried out so far have shown that the extent to which standards are applied in the work of an organization, at least to that exact extent the quality of its products/services has been raised (Čeha, 2014, p. 36) and its business operations has been improved.

\section{Research Methodology}

The research was done with the aim of gaining an insight into how much importance, apart from the other needed factors, Serbian enterprises give to the standardization of business operations as a precondition necessary for sustainable integral competitiveness to develop. The assumption of the research study implies that numerous factors have an influence on the competitiveness of the products and/or business operations of different enterprises, and that, apart from the low level of labor productivity and the inadequate price-product quality ratio, the insufficient application of the quality management system still singles out as the key non-competitiveness problem, especially by small and medium-sized enterprises. 
The research was done as a cross-sectional study of an empirical character in order to describe the importance of the considered factor and the analysis of the relations between the building blocks of the subject-matter factor. Apart from the basic explicative method, the bibliographical speculative method was used in the phase of the establishment of the theoretical framework, whereas in the phase of the processing and interpretation of the results, the methods of multiple comparisons and a statistical test were used. Conducting a survey in order to collect data and pieces of information was used as the research technique in the study.

The research was conducted on a sample of the 136 organizations selected from the database maintained with the Business Registers Agency of the Republic of Serbia, out of which $19 \%$ were micro organizations, $28 \%$ were small organizations, $29 \%$ were medium-sized organizations, while the percentage of large organizations was $24 \%$. The successfulness of their business operations was the decisive factor in selecting the enterprises for the sample.

The questionnaire was aimed at collecting the information about the level of the standardization of business operations in the context of the elements needed for the development of the competitive ability of Serbian organizations. The questionnaire was specially created for the needs of this research study and, apart from the other questions, the same also contained the question: To which extent is the quality concept implemented in the organization according to the requirements imposed by the ISO 9000 standard series in relation to the rank of other performances? The envisaged option implied that the factors could be rated as "very much significant", "they are and they are not significant", and "they are not significant". Taking into account the answers received from the respondents, the differences in the determination of the obstacles in the development of the improvement of the quality of the business operations of the Serbian organizations were processed by the ANOVA test and the nonparametric $\chi^{2}$ test (the existence of a statistically significant difference for the values $\operatorname{Sig} \leq 0.05$ ).

The primary sources of information and types of knowledge were mainly used in the research segment presented in this paper.

\section{Results and discussion}

The analysis of the factors needed for the development of competitiveness as a strategic goal of every national enterprise started with the evaluation of the preselected elements, simultaneously placing an accent on the rating of the standardization of the quality of business operations in relation to the other elements. All the more so given the fact that ever more present international agreements pose challenges of competing with global actors to domestic organizations. Comparative statistic was used to process the independent variables in comparison with the dependent so as to determine the 
connections/relationships and compare certain groups. Based upon the obtained results, it can be concluded that the standardization of the quality of business operations and the purchase of contemporary technological solutions and pieces of equipment were indicated as significant factors (the percentage ranging from $83.8 \%$ to $86.0 \%$ ). The respondents were allowed to rate the factors as "very much needed", "they are needed and they are not needed", and "they are not needed".

Table 1 shows the rates in both absolute and relative indicators for each element needed for the development of the competitive ability. According to the table, it is possible to note that the standardization of the quality of business operations, the continuous improvement of the knowledge of all the employees, the purchase of contemporary technological solutions and pieces of equipment, as well as investment in the development of domestic brands were, in the highest percentage, rated as the "very much needed" elements.

Table 1: The rate of the standardization of the quality of business operations in the context of the elements needed for the development of the competitive ability of the Serbian organizations

\begin{tabular}{|l|c|c|c|c|c|c|}
\hline \multirow{2}{*}{$\begin{array}{l}\text { The elements for the development of the } \\
\text { competitive ability }\end{array}$} & \multicolumn{2}{|c|}{$\begin{array}{c}\text { Very much } \\
\text { needed }\end{array}$} & \multicolumn{2}{|c|}{$\begin{array}{c}\text { It is and it is } \\
\text { not needed }\end{array}$} & \multicolumn{2}{|c|}{$\begin{array}{c}\text { It is not } \\
\text { needed }\end{array}$} \\
\cline { 2 - 7 } & $\mathrm{Af}$ & $\mathrm{Rf}$ & $\mathrm{Af}$ & $\mathrm{Rf}$ & $\mathrm{Af}$ & $\mathrm{Rf}$ \\
\hline $\begin{array}{l}\text { Standardization of the quality of business } \\
\text { operations }\end{array}$ & 114 & 83.8 & 18 & 13.2 & 4 & 2.9 \\
\hline Significant investments in marketing & 77 & 56.6 & 47 & 34.6 & 12 & 8.8 \\
\hline $\begin{array}{l}\text { Investment in the development of domestic } \\
\text { brands }\end{array}$ & 100 & 73.5 & 28 & 20.6 & 8 & 5.9 \\
\hline Building strategic alliances & 78 & 57.4 & 45 & 33.1 & 13 & 9.6 \\
\hline $\begin{array}{l}\text { The application of contemporary } \\
\text { management methods and techniques }\end{array}$ & 81 & 59.6 & 47 & 34.6 & 8 & 5.9 \\
\hline $\begin{array}{l}\text { The continuous improvement of the } \\
\text { knowledge of all the employees }\end{array}$ & 113 & 83.1 & 17 & 12.5 & 6 & 4.4 \\
\hline $\begin{array}{l}\text { The purchase of contemporary technological } \\
\text { solutions and pieces of equipment }\end{array}$ & 117 & 86.0 & 17 & 12.5 & 2 & 1.5 \\
\hline
\end{tabular}

Af - absolute frequencies; Rf - relative frequencies (percentages)

Source: Miletić, 2020, p. 168.

Furthermore, the sample-selected respondents were also asked to rate which key obstacles were present on the way to raising the level of the competitiveness and quality of the business operations of Serbian organizations. The obstacles offered as the options in the questionnaire could be rated by the respondents as "very big", and an obstacle "both big and not big", and as an obstacle which is "not big". In Table 2 below, it is possible to see that the outdated equipment and technologies, a lack of resources, a lack of financial capital, as well as the business operations not based upon the international standards were rated as the biggest obstacles (more than one-half of the respondents rated them as a "very big" obstacle) (Miletić et al., 2019, p. 295). 
Table 2: The rates of the primary obstacles in the development of the competitiveness of domestic enterprises

\begin{tabular}{|l|c|c|c|c|c|c|}
\hline \multirow{2}{*}{$\begin{array}{l}\text { The obstacles in the development of } \\
\text { competitiveness }\end{array}$} & \multicolumn{2}{|c|}{ Very big } & \multicolumn{2}{|c|}{$\begin{array}{c}\text { Both big and } \\
\text { not big }\end{array}$} & \multicolumn{2}{c|}{ Not big } \\
\cline { 2 - 8 } & Af & Rf & Af & Rf & Af & Rf \\
\hline $\begin{array}{l}\text { The inadequate use of contemporary } \\
\text { management methods and techniques }\end{array}$ & 51 & 37.5 & 52 & 38.2 & 33 & 24.3 \\
\hline A lack of resources & 75 & 55.1 & 40 & 29.4 & 21 & 15.4 \\
\hline A lack of knowledge & 67 & 49.3 & 42 & 30.9 & 27 & 19.9 \\
\hline Outdated equipment and technologies & 80 & 58.8 & 37 & 27.2 & 19 & 14.0 \\
\hline A lack of financial capital & 81 & 59.6 & 30 & 22.1 & 25 & 18.4 \\
\hline $\begin{array}{l}\text { The inadequate application of the marketing } \\
\text { concept }\end{array}$ & 46 & 33.8 & 66 & 48.5 & 24 & 17.6 \\
\hline $\begin{array}{l}\text { The insufficiently stimulating business } \\
\text { ambience }\end{array}$ & 61 & 44.9 & 44 & 32.4 & 31 & 22.8 \\
\hline $\begin{array}{l}\text { The business operations not based upon } \\
\text { international standards }\end{array}$ & 56 & 41.2 & 42 & 30.9 & 38 & 27.9 \\
\hline
\end{tabular}

Af - absolute frequencies; Rf - relative frequencies (percentages)

Source: Miletić, 2020, p. 169.

Given the fact that the standards serve to set certain successfulness parameters (KPIs) in order to monitor effects, it can be expected that the enterprise should respond to certain criteria (Popescu, et. al. 2017). For that reason, the organizations were asked to rate the selected characteristics, including the level of the extent to which the quality concept was implemented according to the requirements imposed by the ISO 9000 standard series within the framework of their business operations, with the rates from 1 to 5 , where 1 was the lowest rate, and 5 was the highest. All the more so because of the fact that quality (Simić, 2012) is marked as the backbone of the QMS, which is precisely defined in the said standard series. The results per certain characteristics are presented in Table 3.

Table 3: The rates of some characteristics in the enterprises

\begin{tabular}{|l|c|c|c|c|c|c|c|c|c|c|}
\hline \multirow{2}{*}{ The characteristic } & \multicolumn{9}{|c|}{ R a t e s } \\
\cline { 2 - 10 } & \multicolumn{2}{|c|}{1} & \multicolumn{2}{|c|}{2} & \multicolumn{2}{|c|}{3} & \multicolumn{2}{|c|}{4} & \multicolumn{2}{|c|}{5} \\
\cline { 2 - 10 } & Af & Rf & Af & Rf & Af & Rf & Af & Rf & Af & Rf \\
\hline $\begin{array}{l}\text { The level of } \\
\text { competition on the } \\
\text { market on which the } \\
\text { organization does } \\
\text { business }\end{array}$ & 7 & 5.1 & 12 & 8.8 & 42 & 30.9 & 29 & 21.3 & 46 & 33.8 \\
\hline $\begin{array}{l}\text { The level of the } \\
\text { quality of the products } \\
\text { on the market on } \\
\text { which the } \\
\text { organization does } \\
\text { business }\end{array}$ & 2 & 1.5 & 11 & 8.1 & 49 & 36.0 & 40 & 29.4 & 34 & 25.0 \\
\hline
\end{tabular}




\begin{tabular}{|l|c|c|c|c|c|c|c|c|c|c|}
\hline $\begin{array}{l}\text { The level of the } \\
\text { competitive ability of } \\
\text { the organization }\end{array}$ & 4 & 2.9 & 8 & 5.9 & 30 & 22.1 & 57 & 41.9 & 37 & 27.2 \\
\hline $\begin{array}{l}\text { The technological } \\
\text { level of the } \\
\text { organization }\end{array}$ & 0 & 0 & 15 & 11.0 & 20 & 14.7 & 57 & 41.9 & 44 & 32.4 \\
\hline $\begin{array}{l}\text { The level of the extent } \\
\text { to which the quality } \\
\text { concept is } \\
\text { implemented in the } \\
\text { organization } \\
\text { according to the } \\
\text { requirements of the } \\
\text { ISO 9000 standard } \\
\text { series }\end{array}$ & 13 & 9.6 & 17 & 12.5 & 9 & 6.6 & 41 & 30.1 & 56 & 41.2 \\
\hline
\end{tabular}

Source: Miletić, 2020, p. 169-170.

Table 4 accounts for the rank of the characteristics based upon the average rates (the mean values) for every performance.

Table 4: The level of the extent to which the quality concept is implemented in the organization according to the requirements of the ISO 9000 standard series in relation to the rank of the other performances

\begin{tabular}{|l|c|c|}
\hline \multicolumn{1}{|c|}{ The characteristics } & $\begin{array}{c}\text { The mean } \\
\text { values }\end{array}$ & $\begin{array}{c}\text { The rank of the } \\
\text { performances }\end{array}$ \\
\hline $\begin{array}{l}\text { The organization's quality business operations in relation } \\
\text { to the comparable competitors }\end{array}$ & 4.21 & 1 \\
\hline $\begin{array}{l}\text { The functioning of the organization in relation to the } \\
\text { known external standards }\end{array}$ & 3.97 & 5 \\
\hline The level of the competitive ability of the organization & 3.85 & 10 \\
\hline $\begin{array}{l}\text { The level of the extent to which the quality concept is } \\
\text { implemented in the organization according to the } \\
\text { requirements of the ISO 9000 standard series. }\end{array}$ & 3.81 & 12 \\
\hline $\begin{array}{l}\text { The level of the competition in the market in which the } \\
\text { organization does business }\end{array}$ & 3.70 & 14 \\
\hline $\begin{array}{l}\text { The quality of the products in the market in which the } \\
\text { organization does business }\end{array}$ & 3.68 & 21 \\
\hline $\begin{array}{l}\text { The level of the development of the marketing sector in the } \\
\text { organization }\end{array}$ & 3.30 & 15 \\
\hline
\end{tabular}

Source: Miletić, 2020, p. 172-173.

Based upon the results, it can be seen that, in the organizations included in the sample, qualitative business operations in relation to the comparable competitors, the level of the extent to which the quality concept is implemented in the organization according to the requirements of the ISO 9000 standard series, the functioning of the organization in relation to the known external standards and the level of the competitive ability of the organization are rated best (with an average rate of 4), only to be followed by the performances rated below 3.80: the level of the competition in the 
market in which the organization does business, the level of the development of the marketing sector in the organization, and the quality of the products in the market in which the organization does business (Miletić, Miletić, Berber, 2019, p. 224).

Graph 1 presents the business operations not based upon the international standards and singled out as an obstacle to the development of competitiveness by enterprises of different sizes. The majority of our employees associate a standard with something strict and uncreative, tightly connected with regulations and norms, so every indication of standardization and business operations with us according to the predefined rules is accepted with a dose of disapproval. However, the fact is that, according to the requirements of the ISO 9001 standards, certification increases clients' trust in a product/service and leads towards better positioning in the market.

Graph 1: Business operations not based upon the international standards as an obstacle to the development of competitiveness

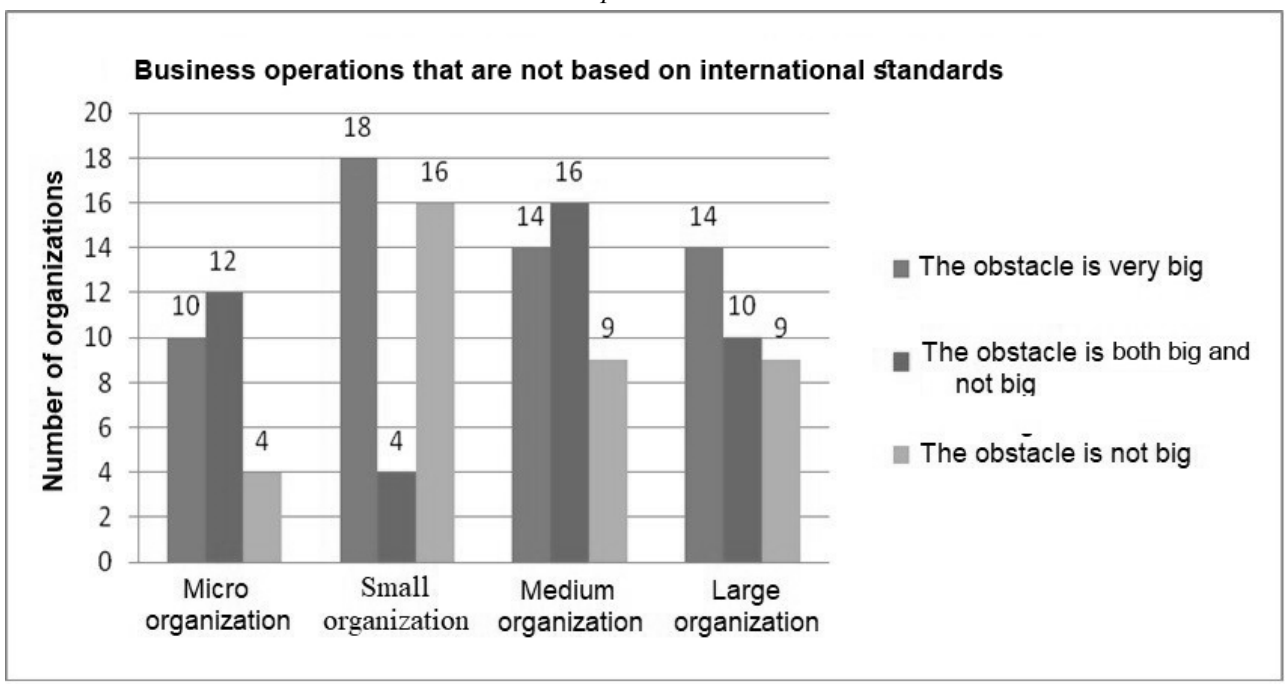

Source: Miletić, 2020, p. 183.

Table 5 shows that Sig. $=0.035<0.05$, so it can be concluded that there is a significant difference in the rates of the business operations not based upon the international standards by the organizations of different sizes as an obstacle to the development of competitiveness.

Table 5: The significance of the difference between the rates of the business operations not based upon the international standards as an obstacle to the development of competitiveness

\begin{tabular}{|l|c|c|c|}
\hline & Value & df & Sig. \\
\hline Pearson Chi-Square $(\chi 2$ Chi Square $)$ & 13.573 & 6 & .035 \\
\hline
\end{tabular}

Source: Miletić, 2020. 
The differences in the determination of the elements needed for the development of the competitive abilities of the Serbian organizations by the organizations of a different level of business operations (the local market, the national market, the regional market, and the international market) were processed by means of the nonparametric $\chi^{2}$ test (the presence of a statistically significant difference for the values $\operatorname{Sig} \leq 0.05)$.

Graph 2 is a presentation of the need for the standardization of the quality of business operations as the element needed for the development of the competitiveness of Serbian enterprises.

Graph 2: The standardization of the quality of business operations as the element needed for the development of the competitiveness of the Serbian organizations

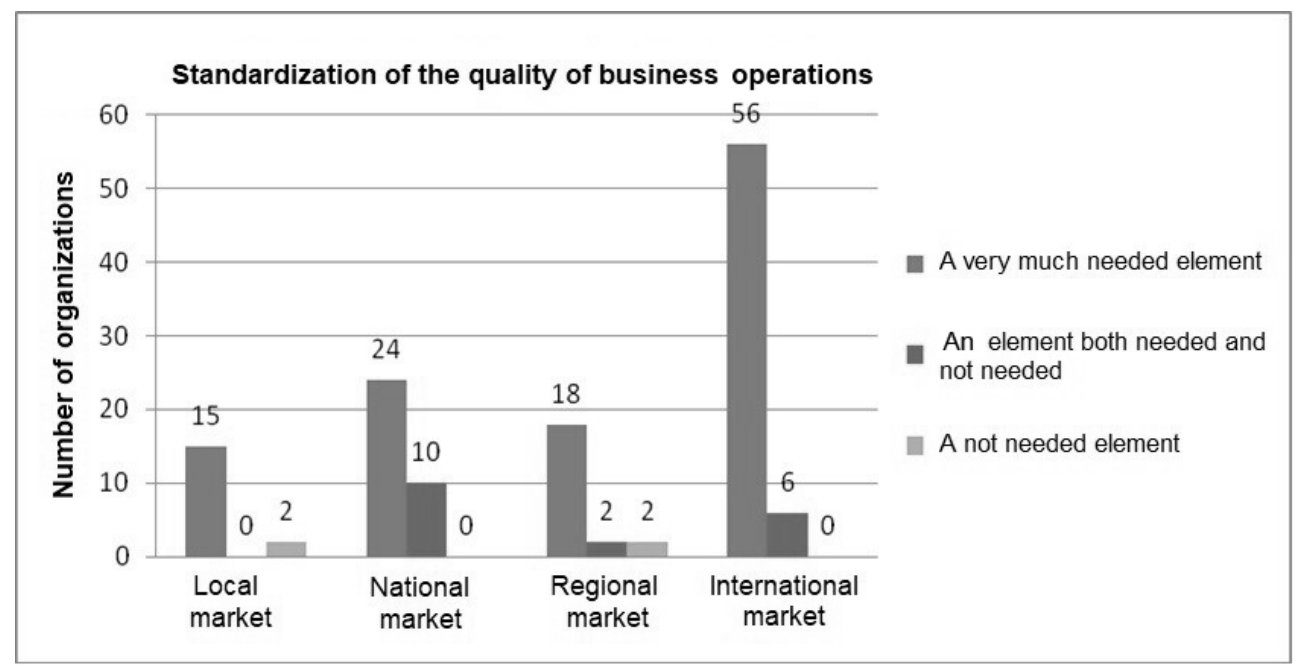

Source: Miletić, 2020, p. 184 (modified).

In Table 6 , it is possible to see that Sig. $=0.002<0.05$, so it can be concluded that there is a significant difference in the rates for the significance of the standardization of the quality of business operations for the development of the competitiveness of the Serbian enterprises, as rated by the organizations of a different level of business operations.

Table 6: The significance of the difference between the rates of the significance of the standardization of the quality of business operations for the development of the competitiveness of the Serbian organizations

\begin{tabular}{|l|c|c|c|}
\hline & Value & $\mathrm{df}$ & Sig. \\
\hline Pearson Chi-Square $(\chi 2$ Chi Square $)$ & 20.903 & 6 & .002 \\
\hline
\end{tabular}

Source: Miletić, 2020.

The respondents from the organizations were also requested to rate certain characteristics in business operations with the rates ranging from 1 to 5 , where 1 was 
the lowest rate, and 5 was the highest. A two-factor analysis established a fact that the number of the years of business operations and the level of business operations (local, national, regional, and international) have an impact on the differences in the characteristics of the organizations as a precondition for the standardization of the quality of business operations. The value 0.05 (for all the values $\mathrm{Sig} \leq 0.05$, there is a statistically significant difference) was taken for the significance level of the difference. The following characteristics were being examined: The level of the extent to which the quality concept is implemented in the organization according to the requirements of the ISO 9000 standard series.

In Table 7, the mean values of the rates of the level of the extent to which the quality concept is implemented according to the requirements of the ISO 9000 standard series in the organizations doing business for a different time period and doing business at a different level are given for each such level and the length of time in business. Standard Deviation (Std. Deviation) is a deviation of the mean value of the rate, and N is the number of the respondents in the sample. It can be seen that the level at which the quality concept is implemented according to the requirements of the ISO 9000 standard series is best rated in the organizations doing business in the international market, and within those organizations in the organizations that have been doing business for a period of time from 11 to 20 years.

Table 7: The mean value of the rates for the level of the extent to which the quality concept is implemented in the organization according to the requirements of the ISO 9000 standard series

\begin{tabular}{|c|c|c|c|c|}
\hline $\begin{array}{l}\text { The level of } \\
\text { business } \\
\text { operations }\end{array}$ & $\begin{array}{l}\text { The length of time in } \\
\text { business of the organization }\end{array}$ & $\begin{array}{l}\text { The mean value } \\
\text { of the rates }\end{array}$ & $\begin{array}{c}\text { Std. } \\
\text { Deviation }\end{array}$ & $\mathrm{N}$ \\
\hline \multirow{5}{*}{$\begin{array}{l}\text { The local } \\
\text { market }\end{array}$} & From 6 to 10 years & 1.00 & .000 & 4 \\
\hline & From 11 to 20 years & 4.00 & .000 & 3 \\
\hline & From 21 to 30 years & 4.25 & .886 & 8 \\
\hline & Over 40 years & 4.00 & .000 & 2 \\
\hline & Total & 3.41 & 1.502 & 17 \\
\hline \multirow{7}{*}{$\begin{array}{l}\text { The national } \\
\text { market }\end{array}$} & Up to 5 years & 4.71 & .488 & 7 \\
\hline & From 6 to 10 years & 5.00 & .000 & 2 \\
\hline & From 11 to 20 years & 3.67 & 1.581 & 9 \\
\hline & From 21 to 30 years & 2.80 & 1.476 & 10 \\
\hline & From 31 to 40 years & 4.00 & .000 & 2 \\
\hline & Over 40 years & 1.50 & .577 & 4 \\
\hline & Total & 3.47 & 1.542 & 34 \\
\hline \multirow{5}{*}{$\begin{array}{l}\text { The regional } \\
\text { market }\end{array}$} & From 6 to 10 years & 5.00 & .000 & 2 \\
\hline & From 11 to 20 years & 1.75 & .463 & 8 \\
\hline & From 21 to 30 years & 3.00 & 1.155 & 4 \\
\hline & Over 40 years & 4.78 & .441 & 9 \\
\hline & Total & 3.43 & 1.532 & 23 \\
\hline The & From 6 to 10 years & 4.13 & 1.187 & 15 \\
\hline
\end{tabular}




\begin{tabular}{|l|l|c|c|c|}
\hline \multirow{3}{*}{$\begin{array}{l}\text { maternational } \\
\text { market }\end{array}$} & From 11 to 20 years & 4.58 & .515 & 12 \\
\cline { 2 - 5 } & From 21 to 30 years & 4.05 & 1.203 & 21 \\
\cline { 2 - 5 } & From 31 to 40 years & 4.00 & .000 & 3 \\
\cline { 2 - 5 } & Over 40 years & 4.45 & .522 & 11 \\
\cline { 2 - 5 } & Total & 4.24 & .970 & 62 \\
\hline \multirow{5}{*}{ Total } & Up to 5 years & 4.71 & .488 & 7 \\
\cline { 2 - 5 } & From 6 to 10 years & 3.74 & 1.630 & 23 \\
\cline { 2 - 5 } & From 11 to 20 years & 3.56 & 1.435 & 32 \\
\cline { 2 - 5 } & From 21 to 30 years & 3.70 & 1.319 & 43 \\
\cline { 2 - 5 } & From 31 to 40 years & 4.00 & .000 & 5 \\
\cline { 2 - 5 } & Over 40 years & 3.08 & 1.230 & 26 \\
\cline { 2 - 5 } & Total & 3.81 & 1.347 & 136 \\
\hline
\end{tabular}

Source: Miletić, 2020, p. 196-198.

The influence of the interaction between the length of time in business of the organization and the level of business operations is given in Table 8. In the column "The level of business operations /The length of time in business, Sig $=0.000$, which less than 0.05 , so it can be concluded that there are significant differences in the rates for the level of the extent to which the quality concept is implemented in the organization according to the requirements of the ISO 9000 standard series. The influence of the interaction between the level of business operations and the length of time in business is statistically significant.

After the analysis of the joint influence, the analysis of the separate influences was carried out. Namely, in the column Sig. for the level of business operations is 0.003 , which is less than 0.05 , so it is concluded that the level of the business operations of the organization has a significant influence on the rates for the level of the extent to which the quality concept is implemented in the organization according to the requirements of the ISO 9000 standard series.

Also, the Sig. for the length of time in business is less than 0.05 , actually being 0.036 , which also significantly influences the differences in the rates. A conclusion is drawn that the level of business operations and the length of time in business play a significant role with respect to the differences in the level of the extent to which the quality concept is implemented in the organization according to the requirements of the ISO 9000 standard series.

Table 8: The influence of the interaction between the variables "the level of business operations" and "the length of time in business" on the rate for the level of the extent to which the quality concept is implemented in the organization according to the requirements of the ISO 9000 standard series

\begin{tabular}{|l|c|c|c|c|}
\hline The variables & Df & Mean Square & F & Sig. \\
\hline The level of business operations & 3 & 4.528 & 4.865 & .003 \\
\hline The length of time in business & 5 & 2.311 & 2.483 & .036 \\
\hline $\begin{array}{l}\text { The level of business operations / The } \\
\text { length of time in business }\end{array}$ & 10 & 9.626 & 10.340 & .000 \\
\hline
\end{tabular}

Source: Miletić, 2020, p. 199. 
It was observed that the individual influences of the level of business operations and the length of time in business differed. A subsequent test determined which organizations especially differed in rates depending upon the level of business operations with the help of the Tukey Test.

In Table 9, it can be seen that the rates of the organizations doing business in the local market and in the international market, in the national market and in the international market, and in the regional market and in the international market specially differ.

Table 9: The comparative analysis of the organizations of a different level of business operations in the rates for the level of the extent to which the quality concept is implemented in the organization according to the requirements of the ISO 9000 standard series

\begin{tabular}{|c|c|c|c|c|c|c|}
\hline \multirow{2}{*}{$\begin{array}{l}\text { (I) The level of } \\
\text { the business } \\
\text { operations of } \\
\text { the organization }\end{array}$} & \multirow{2}{*}{$\begin{array}{l}\text { (J) The level of } \\
\text { the business } \\
\text { operations of } \\
\text { the organization }\end{array}$} & \multirow{2}{*}{$\begin{array}{l}\text { The mean } \\
\text { value of } \\
\text { the } \\
\text { difference } \\
\text { (I-J) }\end{array}$} & \multirow{2}{*}{$\begin{array}{l}\text { Standa } \\
\text { rd } \\
\text { Error }\end{array}$} & \multirow{2}{*}{$\begin{array}{c}\text { The } \\
\text { significance } \\
\text { of the Error } \\
\text { (Sig) }\end{array}$} & \multicolumn{2}{|c|}{$\begin{array}{c}\text { The } 95 \% \text { trust } \\
\text { interval }\end{array}$} \\
\hline & & & & & $\begin{array}{c}\text { The lower } \\
\text { limit }\end{array}$ & $\begin{array}{c}\text { The upper } \\
\text { limit }\end{array}$ \\
\hline \multirow{3}{*}{$\begin{array}{l}\text { The } \\
\text { national } \\
\text { market }\end{array}$} & $\begin{array}{l}\text { The local } \\
\text { market }\end{array}$ & .06 & .287 & .997 & -.69 & .81 \\
\hline & $\begin{array}{l}\text { The regional } \\
\text { market }\end{array}$ & .04 & .260 & .999 & -.64 & .71 \\
\hline & $\begin{array}{l}\text { The } \\
\text { international } \\
\text { market }\end{array}$ & $-.77(*)$ & .206 & .002 & -1.31 & -.23 \\
\hline \multirow[t]{3}{*}{$\begin{array}{l}\text { The regional } \\
\text { market }\end{array}$} & $\begin{array}{l}\text { The local } \\
\text { market }\end{array}$ & .02 & .309 & 1.000 & -.78 & .83 \\
\hline & $\begin{array}{l}\text { The national } \\
\text { market }\end{array}$ & -.04 & .260 & .999 & -.71 & .64 \\
\hline & $\begin{array}{l}\text { The } \\
\text { international } \\
\text { market }\end{array}$ & $-.81(*)$ & .236 & .005 & -1.42 & -.19 \\
\hline \multirow{3}{*}{$\begin{array}{l}\text { The } \\
\text { international } \\
\text { market }\end{array}$} & $\begin{array}{l}\text { The local } \\
\text { market }\end{array}$ & $.83\left(^{*}\right)$ & .264 & .011 & .14 & 1.52 \\
\hline & $\begin{array}{l}\text { The national } \\
\text { market }\end{array}$ & $.77(*)$ & .206 & .002 & .23 & 1.31 \\
\hline & $\begin{array}{l}\text { The regional } \\
\text { market }\end{array}$ & $.81\left(^{*}\right)$ & .236 & .005 & .19 & 1.42 \\
\hline
\end{tabular}

Source: Miletić, 2020, p. 199-200.

\section{Conclusion}

The research results have shown that the standardization of the quality of business operations has been assessed to be a significant factor needed for the development of the competitive ability of the Serbian organizations (with an average rate exceeding 4). The establishment of business operations not based upon the international standards, apart from 
the other factors which are an obstacle to the development of the competitiveness of an enterprise, was rated differently by the respondents employed in the enterprises of a different size.

The answers of the organizations of a different level of business operations were significantly different from each other with respect to the mentioned elements needed for the development of the competitive abilities of domestic enterprises, including the standardization of the quality of business operations as well. Out of the seven observed elements, a significant difference was noticed in six, so a conclusion is made that the level of business operations does significantly influence the rating of the elements needed for the development of the competitive abilities of the organizations.

The length of time in business of the enterprises and the level of business operations have an important, joint influence on all the attributes of the organizations observed as the characteristics a competitive organization should have. As far as individual influences are concerned, it can be noticed that the length of time in business does exert a significant influence on the differences in the level of the extent to which the quality concept is implemented in the organization according to the requirements of the ISO 9000 standard series.

The level of the business operations of an enterprise (i.e. the local market, the national market, the regional market, the international market) has a significant influence on the differences in the following: the level of the extent to which the quality concept is applied in the organization according to the requirements of the ISO 9000 standard series, and the functioning of the organization in relation to the known external standards. It arises that, irrespective of the fact of which activity a concrete enterprise is engaged in, the adoption and maintenance of the standardization system and the quality control system are an important process for its success in the market. Certification according to the requirements of the ISO 9001 standard, which is suitable for all the organizations that want to improve their functioning irrespective of the size or activity of the organization, increases clients' trust in a product/service and leads towards better positioning in the market. Finally, should a concrete organization be unable to function without every day operational engagement, which is a sure sign that time for the standardization of its business operations has come, irrespective of costs.

\section{References}

Aničić, J., Aničić, D., \& Kvrgić, G. (2019). Sustainable growth and regional competitiveness of Serbian economy. Ekonomika, 65(2), 65-74. Doi: https://doi.org/10.5937/ekonomika1902065A

Arsovski, S. (2013). Sinergijski efekat procesa menadžmenta i liderstva. 40. Nacionalna konferencija o kvalitetu FQ2013, Beograd, A-2.

Bobera, D., Strugar-Jelača, M., \& Bjekić, R. (2017). Analysis of leadership styles in medium and large companies on the territory of the Republic of Serbia. Anali Ekonomskog fakulteta u Subotici, 37, 117-127. 
Božilović, S., \& Miletić, V. (2014). Menadžment kvaliteta građevinskih kompanija. Ekonomika, 56(1), 50-59.

Čeha, M. (2014). Analiza aspekata unapređenja kvaliteta poslovanja domaćih organizacija. Kvalitet $i$ izvrsnost, 3-4, 34-37.

Ćurčić, N., \& Miletić, V. (2020). Factors Important or Achieving the Comprtitiveness of Industrial and Agroindustrial Products. Economics of Agriculture, 67(3), 831-849, Doi: https://doi.org/10.5937/ekoPolj2003831C

Cvjetković, M., \& Ilić, D. (2015). Kvalitet u funkciji unapređenja konkurentnosti domaćih preduzeća. Ekonomski izazovi, 4(7), 48-63.

Domazet, I., Zubović, \& Lazić, M. (2018). Driving factors of Serbian competitiveness: digital economy and ICT. Strategic Management, 23(1), 20-28. Doi: https://doi.org/10.5937/StraMan1801020D

ISO 9001. (2015). Sistem menadžmenta kvalitetom - Zahtevi .

Krstić, B., Krstić, M., \& Đekić, I. (2018). Sustainability of development and growth crisis, distribution of income and inequality. Economics of Sustainable Development, 2(1), 1-12.

Miletić, V. (2020). Liderstvo u savremenoj organizaciji. Niš: Ekonomika.

Miletić, V., Ćurčić, N., \& Aničić, D. (2017). Kvalitet srpskih proizvoda - ključ za održivu konkurentnost na otvorenom tržištu, XV Međunarodna multidisciplinarna naučna konferencija "Eurobrand", 24-26 novembar, TQM Center, Zrenjanin, e-Zbornik radova, pp. 73-84.

Miletić, V., Ćurčić, N., \& Miletić, S. (2019). Ocene ključnih faktora unapređenja poslovanja i marketing koncepta u domaćim organizacijama. Vojno delo, 71(2), 289-304, Doi: https://doi.org/10.5937/vojdelo1902289M

Miletić, V., Jovanović, Z. Pavić, Ž. (2020). Evaluation of management methods and techniques regarding quality improvement of Serbian organizations' business. Ekonomika, 66(3), 55-71. Doi: https://doi.org/10.5937/ekonomika2003055M

Miletić, V., Miletić S., \& Berber, N., (2019). How high are the performances of organizations in the Republic of Serbia? Facta Universitatis, Series: Economics and Organization, 16(2), 215-228. Doi: https://doi.org/10.22190/FUEO1902215M

Milovanov, B. (2016). Kvalitet organizacije u svetlu novih verzija standarda za sisteme menadžmenta. Kvalitet i izvrsnost, 9-10, 45-48.

Milunović-Koprivica, S., Bešić, C., \& Ristić, O. (2019). QFD method application in the process of hotel service quality improvement. Hotel and Tourism Management, 7(2), 57-66. Doi: https://doi.org/10.5937/menhottur1902057M

Oakland, J. (2005). Total Quality Management, Grower Handbook of Quality Management, edit. Denis Lock, Gower Press, London. 
Olavarrieta, S., \& Friedmann, R. (2008). Market orientation, knowledge - related resources and firm performance, Journal of Business Research, 61(6), 623-630. Doi: https://doi.org/10.1016/j.jbusres.2007.06.037

Popescu, G. H., Sima, V., Nica, E., \& Gheorghe, I. G. (2017). Measuring sustainable competitiveness in contemporary economies-Insights from European economy. Sustainability, 9(7), 1230. Doi: https://doi.org/10.3390/su9071230

Popović, B. (2013). Svetska klasa kvaliteta. Kvalitet i izvrsnost, 11-12, 33-36.

Šarović, D. (2014). Kreativnost i standardizacija. Kvalitet i izvrsnost, 1-2, 93-95.

Simić, V. (2012). Bitka za kvalitet - društvena, organizaciona, menadžerska, lična. Kvalitet i izvrsnost, 9-10, 17-20.

Soković, M., Jovanović, J., Krivokapić, Z., \& Vujović, A. (2009). Basic quality tools in continuous improvement process. Journal of Mechanical Engineering, 55(5), 333-341. 